\title{
Second World War, Refugee Flow and Forced Migrants in Russia
}

\author{
Boris Kovalev
}

The Twentieth Century can be characterized for Russia as a period of mass migration of its citizens. This process is connected with economic and political factors. A search for a better life took place at the beginning of the century because the national and religious feelings of some nationalities had been abused (namely Jews and Duhobortsi), and also because of economic factors. The western regions of the country were overpopulated and this situation also encouraged Russian migration.

After the revolution of 1917 and the Civil war, millions of participants and representatives of the White movement had to leave their homes because they were defeated. But the events of World War II were far more serious in the sense of testing the nation's ability to survive. The Soviet Union lost 28 million people, a large part of them were civilians. The theory of the race superiority that dominated in fascist Germany encouraged the physical elimination or reduction of the population of the captured countries. The situation was tragic in Russia because Stalin's leadership was mostly concerned with how to save the material wealth, and human lives meant nothing to them.

The priority in the evacuation was given to the equipment of the plants rather than to refugees. The military doctrine of the Soviet Union suggested that the war actions would take place on the enemy's territory only, and this made it impossible even at the beginning of the war to create plans for the mass evacuation of the population of the country. German troops were decisively attacking and moving into the depth of the country in the Summer and Autumn of 1941. The people were

Boris Kovalev, PhD, is a professor of history, Novgorod State University, Russia. This article is dedicated to fifty years after the . end of the Second World War. caught in a total panic. The civil population suffered most of all and this situation created flows of refugees in the country.

The Soviet mass media had created a particular image of a German soldier, and pictured him as a machine-like killer. The flyers and the newspapers were full of descriptions of how children had been killed for entertainment by the German soldiers, how old women had been raped by them, and how historical sites of Russia had been destroyed. As soon as the front line approached, the citizens started to move east on their own. The population in the rural areas created so-called forest settlements. As a rule, they moved into difficult to reach places in the woods, five to seven kilometers away from their homes. In the depths of the woods they built earth shelters and settled there. They hid in the woods until the circumstances regarding German order in the occupied territories was clarified.

The only category of the population of Russia that remained under the control of the Soviet state was Communist and government servants. Those who were considered valuable were evacuated, even by plane, and the rest were devolved to guerilla detachments. According to the survey of the People's Commissariat of Home affairs, Communist Party members and those who sympathized with them feared German punishment and that was why they hid in the forest. They were provided with food and weapons, but many did not how to fight. Very often such detachments stopped to exist. For example, one document reads: "our relatives came into the wood and told us to leave the woods and to return home, because the Germans did not practice repression as described in the Soviet mass media."

The losses of the Soviet Army during the first months of the war were explained to the population of the country by the fact that the traitors in the Army had not been completely eliminated during the mass repression of the Thirties. The leadership of the country feared the creation of a "fifth column" and they undertook certain measures-mass shootings in the prisons and arrests and deportation of undesirable citizens, including Russian Germans who had lived in Russia since the 18th century.

The situation was extremely difficult for the population of the occupied districts. In August and September of 1941, all supervisors of the occupied areas received the order to notify the authorities whether there were refugees, Jews, suspicious people, and foreigners in the areas supervised by them. The order to eliminate all undesirable elements had been given to the punitive detachments. Jews were killed either on the spot or gathered in ghettos. All refugees were considered suspicious and they were arrested. If a refugee managed to prove that he or she had suffered from Bolsheviks or had been related to a German nationality then the Germans used such people and treated them favourably. They sent them back to their native places and provided them with work. Thus all Finns, Estonians, wealthy Russian peasants, and those who had been forcefully moved from their homes and settled on SinjavinoSwamps in the vicinity of Leningrad in the early Thirties, were granted the opportunity to return to their native places.

The relations between the German occupation administration and the local people were of a mixed character. During the first days of the occupation, in order to avoid spreading panic among the population and refugee streams, the Germans abolished taxes, dissolved collective farms, and offered free distribution of goods from the stores. By such measures they tried to 
stabilize the situation. But some weeks later, they restored the taxes and told the citizens that the taxes would be temporary until the end of the war. In their mass media, the Germans put all the responsibility and shame on the Soviet communists. For example, one flyer read: "It is a pity to look at the refugees who have left their homes. The Jewish Bolshevik propaganda has made a nationwide brainwashing. Thousands of women, old people, and children are leaving their native places; they fear German soldiers who have brought them freedom from Stalin's slavery." The name of this flyer was" The happy and the unhappy."

The freedom of the population to move in Russia was very limited late in 1941 and early 1942 after the front line had become more or less steady. The situation was similar on the both sides; occupied and free. In the Soviet zone, the existence of people depended completely on the food ration. The refugees were mainly used in the sphere of production. They were not allowed to leave a factory or a plant where they worked. The punishment was severe imprisonment. Charges were laid for being late for work or for missing a day. The people who had been deported (like Russian-Germans) were used for the most difficult work. This category of people were regularly checked by the People's Commissariat of Home Affairs. In cases where they left a place where they had been settled without permission, they were punished by 10 years of imprisonment in the concentration camp.

On the German side, the so called active population, both those who worked for Germans and those who fought against them, were exposed to maximum danger. The guerillas were hunting policemen, supervisors, trans

lators, and clerks who worked for the proGerman mass-media. If caught they were hanged on the road-crossings, and their bodies were mined. The Germans tried to save their associates

and they moved them to big cities that were reliably protected. From 1943, the Germans started sending them to the Baltic and to Germany. II

Refuge, Vo1. 14, No. 10 (March 1995)

\section{Back Issues of Refuge}

The following is a list of general and thematic issues of Rejitge-Canada's periodical on refugees.

1. Environmental Refugees, VoLl2, No.1, June 1992.

2. Discussion of Immigration Bill C-S6, VoLl2, No.2, July/(Aug.) 1992.

3. General Issue/Refugee Sponsorship, VoL12, No.3, Sept. 1992.

4. Eastern European Refugees, VoLl2, No.4, Oct. 1992.

5. The Tragedy of Somalia, VoLl2, No.5, Nov.lDec. 1992.

6. The Review of Rejected Refugee Claims in Canada,

VoLl2, No.6, January 1993.

7. Russia and Central Eurasia, VoLl2, No.7, February 1993.

8. Africa Issue: Repatriation, VoLl2, No.8, March 1993.

9. General Issue/Globalization, VoLl3, No.1, April 1993.

10. Russia and Central Eurasia, VaLl 3, No.2, May 1993

11. Special Issue on Sri Lanka, VaLl 3, No.3, June 1993.

12. Gender Issues and Refugee Law, VoLl3, No.4, July/Aug. 1993.

13. Southeast Asian Refugees, VoLl3, No.5, Sept. 1993.

14. Mozambican Refugees, VoLl3, No.6, October 1993.

15. Russia and Central Eurasia, VaLl 3, No.7, Nov.lDec. 1993.

16. General Issue/Sudan, VoLl3, No.8, January 1994.

17. Integration of Refugees-The Canadian Experience,

VoLl3, No.9, February 1994.

18. Refugees and Peace in Central America, Vo1.13, No. 10, March 1994.

19. Horn of Africa, VoLl4, No.1, April 1994.

20. The Russian Federation, VoLl4, No.2, May 1994.

21. The Former Yugoslavia, VoLl4, No.3, June/July 1994.

22. General Issue/IRB and Rebuilding Trust/Tamil Immigrants in

Canada, Vo1.14, No.4, Aug./Sept. 1994.

23. Rwandan Crisis, VoLl4, No.5, October 1994.

24. Refugee Resettlement in Israel, VoLl4, No.6, Nov. 1994.

25. Refugee Women- Part 1: Issues, Vo1.14, No.7, Dec. 1994.

26. Refugee Women- Part 2: Case Studies, Vo1.14, No.8,

Jan. 1995.

27. The Safe Third Country Concept, Vo1.14, No.9,

February 1995.

28. Special Issue on Chechnya, Vo1.14, No. 10, March 1995.

Single copy: \$6.50; 10\% discount on 3-9 issues (copies); 20\% discount on 10 issues (copies) or more. Special discounts are available for students and exclusively volunteer-run NGOs. P. O. accepted.

Please send your orders to:

York Lanes Press, Suite 351, York Lanes

Centre for Refugee Studies, York University

North York, Ontario Canada M3J IP3.

Fax: (416) 736-5837 ${ }^{\bullet}$ Internet: refuge@vrn1.yorku.ca 